\title{
Practice of Folk Medicine by Rajbanshis of Sub-Himalayan Bengal: A Study in Historical Perspective ${ }^{\wedge}$
}

\author{
Rup Kumar Barman*
}

Department of History, Jadavpur University, Kolkata-700032

\section{Introduction}

'Folk medicine', an essential feature of human civilization, is still in existence all across the world both in pristine and institutionalized form. In the global context, the medicinal practices of the indigenous communities of Sub-Himalayan Bengal [Jalpaiguri, Alipurduar and Cooch Behar districts of West Bengal] are no exception. Here, the indigenous caste and tribal communities have developed their own curative and preventive medicinal practices with their experience and interactions with flora and fauna of their habitation. Among them, the wide knowledge on folk medicine, preventive food habits, folk culture and health keeping behaviour of the Rajbanshis deserve special attention.

Being the members of the largest indigenous community of Sub-Himalayan Bengal, the Rajbanshis were the main sufferers of different diseases common in this region. In the pre-colonial and early colonial days, common and poor Rajbanshis of this region were solely dependent on their own village medicine. However, with the introduction of modern medical practices especially after the development of indirect British rule in the Cooch Behar State $(1773 \mathrm{CE})$ and direct British rule in Jalpaiguri (in $1869 \mathrm{CE}$ ); the traditional healing practices of this region began to be discouraged. Inspite of it, the Rajbanshis of remote villages of Sub-Himalayan Bengal, have maintained their traditional knowledge on medicinal plants, herbs, and food practice. They have developed their (i) own mechanism in making herbal medicine and drugs with available natural elements, (ii) foodstuff for consumption

DOI: $10.16943 / \mathrm{ijhs} / 2019 / \mathrm{v5} 4 \mathrm{i} 3 / 49750$

*Email: rupkumarbarman@gmail.com

"The Project was carried out under the sponsorship of Indian National Commission for History of Science between the period July 2017 to December 2018. for healing, and (iii) magical means (exorcism) for healing illness. In such a background, this project seeks to highlight the following points for historicizing the medicinal practices of the Rajbanshis of colonial Sub-Himalayan Bengal and their continuity in the post-colonial period, i.e. (i) to make a preliminary idea about the serious diseases and common ailments prevailing in the Sub-Himalayan West Bengal, (ii) to understand the changing attitudes of the Rajbanshis towards disease, (iii) to construct a brief history of folk medicinal practices of the Rajbanshis, and (iv) to highlight the continuity and prosperity of folk medicine of the Rajbanshis along with the process of transmission of knowledge of traditional medicine.

The primary methodology followed in this research involved (i) the collection of primary and secondary data from published sources from different repositories, (ii) identification of medicinal plants and minerals and understanding the drug making process by the community members of the present study, (iii) comparison of secondary sources with the data collected through fieldworks, and (iv) analysis of sources with a scientific perspective for constructing a brief history of folk medicine of the Rajbanshis.

The objectives of the project and methodology have been executed under the following heads:

1. Introduction

2. Geo-societal background of the Rajbanshis of SubHimalayan Bengal.

3. Common diseases of Sub-Himalayan Bengal and attitude of the Rajbanshis.

4. Folk medicine of the Rajbanshis.

5. Magical means of healing and exorcism.

6. Concluding observations.

7. Appendices (1) Drugs and minerals commonly used by the Rajbanshis (2) List of plants used for healing different diseases ( 3 \& 4) Brief description of the Rajbanshi 
healers and their prescriptions (5) Use of magical incantation in folk medicinal practices of the Rajbanshis.

8. Bibliography

\section{Discussion}

The project begins with a brief introduction on the objectives, methodology and importance of the study and survey of published historical researches on the folk medicinal practices of the Rajbanshis. The first chapter explores the geographical and environmental features of Sub-Himalayan Bengal evaluating the relationship between the vegetation, wildlife and climate of the region and the diseases and healing practices of the indigenous communities. This comprises of three districts of northern part of West Bengal [like Cooch Behar, Jalpaiguri and Alipurduar] having a close socio-cultural relationship with Lower Assam and northern Bangladesh (Figure 1). As a geographical region; Sub-Himalayan Bengal has been marked by the natural boundaries since the ancient period. Bhutan, a landlocked Himalayan country, is situated in the northern side while the confluence of the Brahmaputra and the Lakshya rivers in Bangladesh is considered to be southernmost point. The Tista and the Karatoya rivers set the western frontier while historically the eastern boundary of this region is considered to be extended as far as the Sankosh and the Brahmaputra river.

A chain of rivers, hill streams and internal water bodies are the sources of water both for drinking and irrigation. However, they carry calcium carbonate and contaminated water throughout the rainy season and coupled with flood it increases the breeding of mosquitos leading to malaria. A sizable portion of Sub-Himalayan Bengal is covered with deep forest. Jalpaiguri and Alipurduar districts have a total 1790 sq. km forest area. Plenty of jungle and forests in foothill with wild animals of large varieties are again connected with the folk medicinal practice of the indigenous people of the region. All these features have placed this region as a notable area of ethno-botany.

The chapter one also discusses in detail the societal structure of Sub-Himalayan Bengal. Taking clue from the precolonial literatures (like the Kālikā Purāna, 12th CE, Yoginī Tantra, 18th CE and Tabaqāt-I Nasiri, 13th $\mathrm{CE}$ ), this report examines the tribal (Koch, Mech, Rabha, Tharu, etc.) and the Indo-Aryan (Brahmins, Kayasthyas, Daivagnas, Bhuiyans, etc.) culture of the region. The administrative records show that the Sub-Himalayan region had received a considerable number of tribal communities (like the Santhals, Mundas, Oraons, Mahalis, etc.) from the Chhotonagpur region under the colonial rule. The 'forced' and 'voluntary' migrations from East Bengal (Bangladesh) as well as from other states of India have increased the population complexity of the region in the post-colonial period.

According to 2011 census, Rajbanshis are predominantly rural people (92.35\%) having a share of $37.67 \%$ of total population $(10,63,369$ out of total $28,22,780)$ in Cooch Behar and $23.84 \%$ of the total population $(9,22,603$ out of 38,69,675) in Jalpaiguri (including Alipurduar). At present Rajbanshis are Scheduled Caste (SC) community often referred as linguistic community of India, Bangladesh and Nepal. In the colonial days, they had developed a social integrity through their shared linguistic and cultural features and the social reform movement popularly known as kshatriyaization or a movement for social justice. Social identity of the Rajbanshis had appeared as a matter of confusion in the mid-twentieth century India due to the partition of Bengal (1947) and dispersed presence of the Rajbanshis in Bihar, Assam, Meghalaya and other states of Northeast India. However, the postcolonial concept of 'Rajbanshi' (greater KochRajbanshi) means indigenous people those who have adopted Rajbanshi/ Kamtapuri language as their lingua franca [including the Rajbanshis, Koches, Paliyas and local Muslims (called Nashya Shaikhs) of North Bengal and Northeast India].

\section{Common diseases of Sub-Himalayan Bengal and attitudes of the Rajbanshis}

The second chapter of the report highlights the common diseases of Sub-Himalayan Bengal and traditional attitude of the Rajbanshis towards them. The colonial administrators left many valuable records on the common diseases, climate and causes of disease of the region. W. W. Hunter had observed in the 1870s:

The chief diseases that prevail in Kuch Behar (Cooch Behar) are dysentery, malarious fevers, spleen, goitre, and venereal diseases. The first two may be attributed to the dampness of the soil and humidity of the climate, together with 


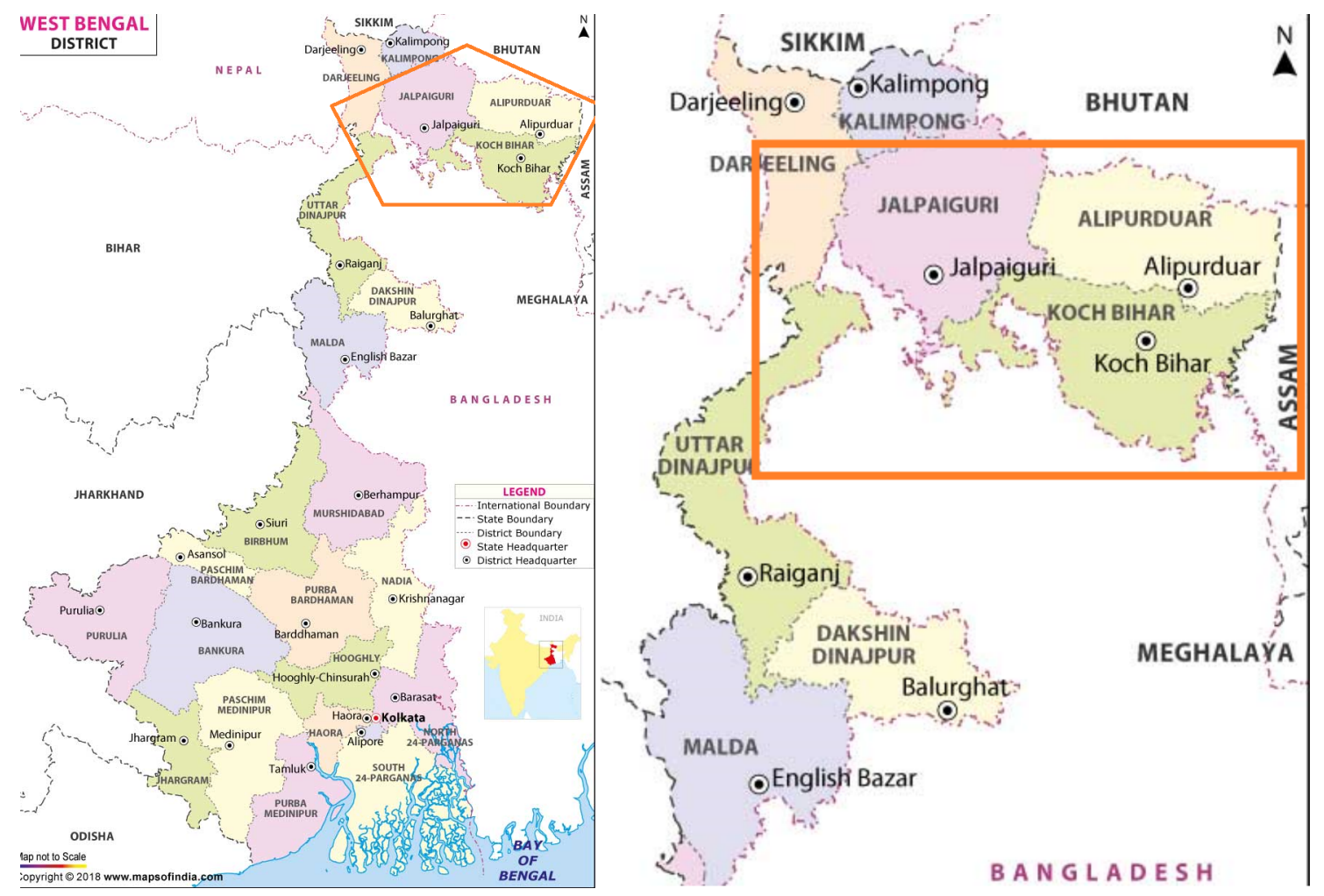

Figure 1 Sub-Himalayan Bengal and the region of concentration of the Rajbanshis.

the exclusive heat during the day in the summer months, followed by the sudden cold after sunset. Goitre is attributed to drinking the water of certain streams (Hunter, 1876, p. 441).

History of diseases did not change its character in the early twentieth century Cooch Behar too. Annual Administrative Reports of Cooch Behar State (1883-1946) and the monumental report of H. N. Chaudhuri (1903) mentioned that cholera (Garmari) was a common epidemic in Cooch Behar. Small pox (Thakurani) was not as frequent as cholera. Leprosy was another common occurrence in Cooch Behar in the colonial days. Other common diseases included fever, whooping cough, dyspepsia, goitre or Derbyshire-neck (locally called ghag), blindness, deafmutism and insanity. Cholera, small pox and malarial fever continued to be a matter of concern due to their fatal characters and inadequacy of medical facility. The Annual Report of 1907-08 of the Cooch Behar State recorded 2,167 cases of cholera and 10,668 cases of malarial fever.

Condition of the Duars area of Jalpaiguri was in no way different because of close proximity with Cooch Be- har and similar geographical and societal set up. The people of Jalpaiguri including present day Alipurdur used to suffer from the common diseases like diarrhea, dysentery, goitre (called bawa in Duars), scurvy, cholera, etc. A firsthand report on the common diseases of Jalpaiguri [including diarrhea, dysentery, goitre, spleen, cholera and malarial fever] has been found in the D. H. E. Sunder's report (1895). J. A. Milligan, the settlement officer of Jalpaiguri (1906-1916) had also recorded the severity of the fatal diseases of Jalpaiguri of the first quarter of the twentieth century especially of malaria. The Malaria Commission of the Royal Society visited the Duars region in 1901 and found that "the malaria indemnity of Duars was extraordinarily high and that black-water fever was common in that locality." However, malarious fever was not a serious problem for the indigenous/ tribal communities of this region [like the Meches and the Rajbanshis]. But other common diseases of Sub-Himalayan Bengal were equally serious to the Rajbanshis.

As an indigenous community, the Rajbanshis had innovated medicinal practices for healing the serious diseases and common ailments with three specific attitudes- (a) 
healing through folk medicine, (b) healing ailment by magic and propitiation of spirits, and (c) discarding the incurable patients or keeping them isolated. From the precolonial sources it is found that discarding the patients with incurable diseases and self-immersion in the sacred rivers were very much common. The 'Darang Raj Vamsavali' (18th century text) has recorded the death of Chilarai, the Koch military general of the 16th century. It described that being affected by small pox Chilarai died in 1571 CE on the bank of Ganges. He was discarded by the people, even by his followers. The Rajbanshis also developed the tradition of isolating the patients with infectious diseases. H. N. Choudhuri recorded in 1903 that:

when any member of a household is attacked with cholera, the house is shunned by the neighbours, and even the friends of the sufferer fear to approach him and nurse him. The victim is left in a hut with a pot of water to shift for himself, so long as strength lasts, and at last dies a horrible death without sympathy and care. It is no wonder therefore that cholera often desolates entire households and towns or villages (Choudhuri, 1903, p. 150).

The Rajbanshis had also developed the tradition of propitiating certain spirits considered to be responsible for epidemics [such as cholera and small pox]. The colonial records show that the Rajbanshi villagers used to believe that the diseases are the outcome of the bad gaze of the malevolent spirits/ demi-gods/ deities [called deo, jokha, jokhi, thakurani such as-Masan Deo, Padma, Kali, Chandi, Bishahari Kanduni Deo, Mina Thakurani, Bao Deo, Balaram-Hanuman-Ram, Chamok Deo, Gorakhnath, Basanta Thakurani, etc. They followed magical means of healing and exorcism for their propitiation. Belief in supernatural beings and propitiation of the demi-gods for healing was actually the outcome of the non-availability of modern medical facilities like hospitals, doctors and dispensaries. The modern hospitals of Jalpaiguri [with charitable dispensaries at Alipurduar, Falakata, Mainaguri and Kumargramduar] and Cooch Behar [with dispensaries at Dinhata, Mathabhanga, Mekhaliganj, Phulbari and Haldibari] were in no way sufficient for healing the ailments of the rural native people. So it is found that the inadequacy of modern medical facility had compelled the Rajbanshis to be more de- pendent on the magical means of healing and maintaining the folk medicine at least within their own community.

\section{Folk medicine of the Rajbanshis: Practice, practitioners and institutions}

The folk medicine often termed as 'traditional medicine' is a global phenomenon. It is widely used in India as a health seeking behaviour especially where mainstay health care is not available. Its features are: (a) it is oral and transmitted through oral traditions, (b) it is based on locally available fauna, flora and minerals, (c) it encompasses important areas of healthcare [like mother and childcare, treatment of common ailments, first aid, nutrition and home remedies]. It also deals with broken bones, poisonous bites of snake and other animals, veterinary care and treatment, (d) 'Nature specific communityculture' is related to the healthcare, and (e) it practices magical-religious form of healing. The third chapter analyses the folk medicinal practices of the Rajbanshis under two heads (i) use of herbs for healing, and (ii) consumption of herbs and vegetables as preventive food habits.

It was observed that till the early 20 th century the Rajbanshis were solely dependent on their folk medicine. H. N. Chaudhuri wrote about the Rajbanshis of Cooch Behar in 1903:

\section{'people very seldom use either Western or Ayurvedic medicines. They are ordinarily treated by the ojhas or villages quacks, who in addition to offering pujas to offended deo or spirit, administer some native drugs.'}

In the pre-colonial and colonial days, the Rajbanshis used to treat small pox, chicken pox and measles with the local drugs and herbs. Consumption of blend of neem (Azadirachta indica) and honey in specific dose in early morning in an empty stomach was a common medicine for pox. To cure ulcer generated from pox, they do use the blend of neem juice and mustard oil [extracted by traditional method]. Simultaneously, water with leaves of chepti kalai and neem is used for bathing of the patient.

For healing cold fever, the Rajbanshis generally use the blend of tulsi (Ocimum sanctum) leaves and honey, basak (Adhatoda vasica) juice and the blend of kalo jeera (Nigella sativa), garlic and mustard oil. Leaves of shiuli 
(Nyctanthes arbortristis) are very much useful in case of black fever. In case of bowel complaint due to diarrhea, the Rajbanshis use the juice of patharkuchi (Kalanchoe pinnata Pers) leaves and gandhabhadal leaves. In dysentery, they prescribe the use of the thankuni leaves (Centella asiatica), boalida leaves, blend of golmorich (black peeper), ginger and leaves of sangibhar, etc. For healing dysentery, they use two other methods: (a) Blend or mixture of atia kala or beechi kala (a kind of banana full with seeds, Musa Paradisiaca) (b) Blend of green leaves of bhant plant (Clerodendrum vicusum) and native guava (in tablet form). For blood clotting from an injury, the Rajbanshis generally use the juice of bisallakarani. Serum of kalokachu, leaves of marigold and udarbhusi plants and durbba grass are also very much helpful for blood clotting.

Jaundice is very much common in Sub-Himalayan region and is known by different names like kumli, kumali, kamela, haldiberam, kaun, etc. among the Rajbanshis. The commonly used methods for healing jaundice are as follows: (a) use of jambura/ batabi lebu (Citrus maxima) and the juice from bark of sajina/sajna (Moringa oleifera) tree, swarnalata, neem, patal leaves and tauri kelai, etc. as medicine. They also suggest the blend of green leaves of kala khesari and milk of goat in the early morning. (b) Second method is a combination of exorcism, medicine and therapy. In this method, they perform a ritual called bharan. This ritual is performed in the early morning and the patient is asked to keep a blend of leaves of bandar nauka plant on his head for two to three hours. In case of non-availability of bandar nauka, they prefer to use the blend of mustard oil, bhogmana (Colocasiaesculenta). Along with this blend they do prescribe incantation. For whooping cough, Rajbanshis generally use the blend of juice of basak, labanga (Syzygium), elachi (cardamom) and kalojera (Nigella sativa). In case of ulcer and wound, the mixture of neem, oil extracted from endi tree, kelai khesary and mustard oil blend are the traditional medicines for them.

The chapter three explores that the folk medicine of the Rajbanshis is largely based on the locally available plants and their sub-products including roots, fruits, flower, bark, etc. While some of the plants are well-known to others, some of them are very much indigenous. In many occasions, we could not trace their botanical name. Some of them are given in appendix 1.

In our fieldwork we have also noticed the use of lo- cal plants in folk medicinal practices of the Rajbanshis. Among them, mention may be made of kankisa/ dandakalas (Leucas cephalotes), shati/ shuti, biskatali, kanta khuria, mongamari, mahabali/buch, kanai dinga [surimala/ dingdinga], gultai, jharua narshing, dhola manamani, joka, pundi, darua haldi, bishmana, dharamana, charakmuni, bahutara, jatrasishi, havvina bish, gakghurkanta, jayatri, chai, kalamichri, damad, padma gulancha, pankira, bhuintinta, bakulkanta, hatubhnga, hanru gach, tokma, dhhulai, bhogmana, kur haldi, chanda, bhat, kechua bish, japsiri, bankapasi, hendar pata, rakhal nadu, kachuripana (water hyacinth), etc. The use of these plants in folk medicinal practices among the Rajbanshis is still prevalent. Rajbanshis also use of different types of minerals for medicinal purposes. Among them phutkuri (allum), rasanjan (suphuret of mercury), sankha (arsenic), kharimati (chalik), tuta (sulphate of copper), hira-khas (sulphate of iron), raskapu (colomel), murdhan shankar (oxide of lead), sorali (nitrate of potash), tabashir (silicate of potash), sajimati (carbonate of soda), sohaga (bicarbonate of soda), Gandhak (sulphur), etc. are very much common.

Food habit is an important part of folk medicine. The third chapter explores that the Rajbanshis have developed a specific use of herbs and vegetables and their subproducts in food habits as a preventive measure of certain diseases. Food habits of the Rajbanshis (including a few special dishes like chheka, pelka, horpa, etc.) in many cases, they prevent the disease or contribute for healing. Making of chheka (or calcium carbonate) from the plantain tuber or bark of mustard seed was/ is a common tradition among the Rajbanshis of North Bengal and Assam. Siddal (dried cake of dry fish with vegetable substance), pelka (light juice made with different leaves and vegetables) and chheka were/ are closely associated with the food-culture of the Rajbanshis.

The healers or the practitioners of folk medicine among the Rajbanshis are mostly ordinary people who are engaged in different occupations [including as cultivators, agricultural labourers, domestic workers, teachers, housewives and even the higher educated people]. They use their knowledge on medicine in their daily life with a perspective of service or for self-requirement. Both men and women carry the knowledge on medicine. It is being transmitted from generation to generation through oral and practical traditions. In fieldwork, we found that the 
practitioners of folk medicine generally do not receive any fee for their services especially where source of medicine [plants, leaves, roots, etc.] are easily available.

However, knowledge of the Rajbanshis on folk medicine is gradually getting an institutionalized form in Cooch Behar, Alipurduar and Jalpaiguri districts. Shri Rajmohan Eshor [the Royal Physician of the Cooch Behar State (c1540-1949 CE)] had developed a special school of healing of fracture and arthritis and a few diseases at Nishiganj of Cooch Behar. This knowledge has been transmitted to the present generation of that family [and the disciple of the Eshore family]. The branches of this family have opened up several clinics at Nishiganj as well as other places of Cooch Behar, Jalpaiguri and Alipurduar. Patients frequently come from different places of north Bengal and north east India. The knowledge of Rajmohan Eshore on the particular branch of medicine has also been transmitted to his disciples and extended to almost entire Sub-Himalayan Bengal in the form of clinics where patients are getting services by paying a suitable amount.

\section{Magical means of healing and exorcism}

Magical-religious beliefs are essentially linked with the folk medicinal practices of the indigenous communities e.g. the practice of black magic and its tools, method and exorcists of Kamarupa-Kamata (precolonial lower Assam and a North Bengal). Literary and historical texts of this region have left some impression about the practices of magical means as medical exorcism and as 'offensive charm'. The fourth chapter of the report highlights the tradition of magical belief of the Rajbanshis which continued to survive during the colonial period. Buchanan Hamilton during his visit (1808-1814) to Kamtapur fort had recorded that people of this region were very much superstitious and dependent on miraculous incidents. He described in detail about different magical means for healing and charming by performers of magical rites. During the field work we heard about two types of exorcism(i) magical means of healing, and (ii) black magic for charming. Rajbanshi villagers held the view that certain evil spirits were/ are responsible for their diseases. Hence, their propitiation was/ is very much common in Sub-Himalayan Bengal and Lower Assam. Masan [with large varieties], dhumbaba, poiry [with large variation], bhuts (male spirits), pettani (female spirits), etc., were/ are common spirits of the Sub-Himalayan Bengal [as associated with the lives of the Rajbanshi]. For the propitiation of the evil spirits, the Rajbanshis used to call an exorcist who would generally treat the affected person with different sanctified things, magic and incantation as per tradition. Rajbanshis do use different sanctified things as protective means such as morcha kharu (anklet), hoidddar māla [necklace with beads in black string], iron [as a protective metal], dhap/talisman, etc.

Practice of black magic such as throwing magical arrow, especially to disturb the enemies, was/ is another common trend among the Rajbanshis. Charu Chandra Sanyal had recorded the tradition of charming arrows practiced by the Rajbanshi charmers of the late twentieth century. According to him, most common bāna practiced by the Rajbanshis were/ are -Baro Gopalur, Tepa, Howatepa, Meheri, Masna, Juguni, Brahma bāna etc. This magical charming is now extinct.

\section{Concluding remarks}

The present study has noticed that the geographical features have immense influence on the settlement pattern, belief system and folk medicine of the Rajbanshis. They have maintained three basic trends. Firstly, parts and sub-products of different varieties of plants [including their leaves, barks, roots, flowers, fruits, natural gum, and natural resinous materials] and easily procurable minerals are used by the Rajbanshis for healing different diseases. However, due to deforestation and environmental changes many species of plants are no more available in this region. So the expert Rajbanshi healers are now importing them from other states of India or collecting them from the wholesale markets. Because of traditions and professional ethics, the knowledge of the Rajbanshi healers is restricted within the community. It is being transmitted only through family traditions or through 'teacherpupil traditions' (guru-śisya paramparā). So they generally don't disclose the method of preparation of medicine to the outsiders. The practices of folk medicine were basically non-profiting and confined to providing services to their community members only. So they generally don't receive a fee for their service except for cost of medicine as per the capacity of patients. At present 'Mushuru Baidya 
School of Healing of Nishiganj' is gaining an institutionalized from especially for treatment of bone-facture, joint pain, arthritis, jaundice, paralysis, piles and 'dhāta syndrome'.

Second feature points to the use of magical means for improving mental strength of patients to fight against ailments. Here, sanctified oil, water and tabiz (talisman) are prescribed to the patients along with the performance of the religious rituals. However, the present generation of the Rajbanshis doesn't think that the spirits are responsible for disease. They merely maintained the traditions of worshipping and propitiating spirits as a part of their folk-culture.

Thirdly, it was found that the traditional food habits of the Rajbanshis and 'diet chart' are very much healthy in nature. Preparation and consumption of certain dishes and foods like chheka, pelka, siddal, ding, phoktai, horpa, local sower curd, different kinds of leaves, roots and wild fruits like jamri (wild citrus lemon), lotkon, wild berry, etc. are very much preventive and curative in nature. Although the present generation prefers to consume the popular foods of present day but the old generation of the Rajbanshis of Sub-Himalayan Bengal often talks about their own food!

\section{Appendix 1}

\section{Plants used in folk medicine of the Rajbanshis}

1. basak (Adhatoda zeylanica)

2. neem (Azadirachata indica)

3. bhant (Clerodendronviscosum)

4. ishanmul (Aristolochia indica)

5. satamuli (Asparagus sarmentosus)

6. pudina (Mentha sativa)

7. anantamul (Hemidesmus indica)

8. gulancha (Tinospora cordifolia)

9. dhatura (Datura stramonium)

10. upang (Achyaranthesaspera)

11. sialkanta (Argemone mexicana)

12. amla (Phyllanthus emblica)

13. ajawan, sajina (Moringa oleifera)

14. ada (Zingaiber officinale)

15. rasun (Allium sativum)

16. tentul (Tarmarindus indica)

17. kala sarisaha (Brassica nigra)
18. sada sarisha (white mustard seed)

19. pipul (Ficus religiosa)

20. amrul (Oxalis corniculata)

21. haritaki (Terminalia chebula)

22. golmarich (Piper nigrum)

23. ban tulsi, ram tulsi (Ocimum americanum)

24. kalojira (Nigella sativa)

25. satamul (Aspaeagus racemosus)

26. shiuli (Nyctanthes arbor-tristis)

27. chhatim (Alstonia scholaris)

28. halud (Curcuma longa)

29. bel (Aegle marmelos)

30. lajjwabati (Mimosa pudica)

31. shimul (Bombax ceiba)

32. tejpata (Cinnamomum tamala)

\section{Bibliography}

[1] Suryakhari, Daivagna. Darrang Raj Vamsavali, N. C. Sharma (Ed.), Pathsala, Bani Prakash, 1973.

[2] Barman, Upendra Nath. Sekaler Uttar Bangla $O$ Amar Jiban Smriti, Bijay Chandra Barman, Jalpaiguri, 1985.

[3] Mandal, Tanay. Rajbangshi Lokachikitsha, Government of West Bengal, Kolkata, 2011.

[4] Chaudhuri, Harendra Narayan, The Cooch Behar State and its Land Revenue Settlements, The Cooch Behar State Press, Cooch Behar, 1903.

[5] Hunter, W. W. Statistical Account of Bengal, Vol. X, Darjeeling, Jalpaiguri and Cooch Behar, 1876, Trubner \& Cong, London 1876, reprint edition, Concept Publishing House, Delhi 1984.

[6] Kushari, Abani Mohun (et. al). West Bengal District Gazetteers: Jalpaiguri, Government of West Bengal, Calcutta, 1981.

[7] Martin, Montgomery, The History, Antiquities, Topography and Statistics of Eastern India, 5 Vols. WH Allen and Co, London, 1838, reprint edition, Cosmo Publications, Delhi, 1976.

[8] Miligan, J. A. Final Report on the Survey and Settlement Operation in the Jalpaiguri District, Bengal Secretariat Book Depot, Calcutta, 1919. 
[9] Sanyal, Charu Chandra. The Rajbanshis of North Bengal, reprint edition, The Asiatic Society, Kolkata, 2002.

[10] Sunder, D. H. E. Survey and Settlement of the Western Duars in the District of Jalpaiguri 1889-95, Bengal Secretariat Press, Calcutta,1895. 